The final publication is available in: Transportation Research Part A 118 (2018), 305-318, https://doi.org/10.1016/j.tra.2018.09.010.

\title{
Public support of transport policy instruments, perceived transport quality and satisfaction with democracy. What is the relationship?
}

Petter Christiansen, Institute of Transport Economics and University of Oslo, pch@toi.no, Gaustadallen 21, 0349 Oslo, Tel.; +4722573800

\section{Abstract}

Lack of public support is regarded as a major barrier for implementing restrictive transport policy instruments. Recent studies have therefore analyzed factors explaining variations in public support and examined strategies to increase support of restrictive policy measures. However, few have analyzed whether there is an actual relationship between transportation policies and political legitimacy. This article thus makes two main contributions to the literature. First, it explores whether there is a relationship between support of restrictive instruments and political legitimacy to study the political implications of introducing such instruments. The results show that citizens opposing restrictive measures, such as local road tolls, are more dissatisfied with the performance of local democracy. The effect also appears to be mediated through citizens evaluation of politicians' and how they evaluate governmental performance at the local level. Second, the article analyzes the importance of transportation policies in particular for local political legitimacy. The results show that citizens dissatisfied with the quality of services within the transport sector are also more dissatisfied with the performance of local democracy.

Keywords: acceptance; transport policy; restrictive instruments; toll cordon system; satisfaction with democracy; political legitimacy

\section{Introduction}

This article contributes to the literature on acceptance and support for restrictive policy instruments by analyzing the relationship between political legitimacy and the use of such instruments. While most studies have focused on measuring opposition or explaining variations in support (Eliasson, 2014; Eliasson and Jonsson, 2011; Hårsman and Quigley, 2010; Albalate and Bel, 2009; Börjesson et al., 2016; Schade and Baum, 2007), few have analyzed whether there is an actual relationship between opposition towards restrictive instruments and satisfaction with democracy.

According to Salamon (2002:24), "tool choice can affect the overall sense of legitimacy that government enjoys in the eyes of the citizens". While these claims may be theoretically wellfounded, there are few articles that empirical analyze whether the implementation of unpopular instruments have any impact on political legitimacy. This is an important field of study since scholars have argued that when citizens have positive attitudes towards the political system they are less likely to push for radical changes (Bernauer and Vatter, 2012:435). It is therefore important to understand the mechanisms explaining citizens' satisfaction with how democracy works and, in doing so, to analyze the importance of transportation policies for political legitimacy. Thus, the purpose of this article is to analyze if, and how, the use of specific policy instruments in the transportation sector can influence satisfaction with democracy (BemelmansVidec et al., 2011).

This is an especially relevant topic considering the challenges governments face in seeking to achieve targets for reducing GHG-emissions. Congestion and emissions from transport are frequently mentioned as examples of wicked problems. Use of restrictive policy instruments is commonly seen as necessary in order to address many of the negative consequences associated 
with such problems (Börjesson et al., 2012). But congestion pricing and tolls have proven to be highly controversial instruments which meet fierce public and political opposition in many cities (Rye et al., 2008; Eliasson and Jonsson, 2011; Börjesson and Kristoffersson, 2015). The lack of public, and hence political, support has therefore been suggested as a main reason for why such instruments are not adopted and introduced (Santos, 2008).

This article also contributes to the literature on political legitimacy. First, although there are several studies analyzing political legitimacy at the local and regional level (e.g. Rose and Pettersen, 2009b, 2000, 1999; Weitz-Shapiro, 2008; Vetter, 2007), few have analyzed the specific role and importance of transportation policies. This is especially important since, according to Wagner et al. (2009), we still lack knowledge on 'what drives subjective perceptions of satisfaction with democracy'. In the Nordic countries, municipals exercise substantial influence over policies relevant to peoples' satisfaction with local democracy (Denters and Rose, 2005). The performance of subnational levels of government in these countries is thus likely to play a key role for citizens' evaluations of democracy, especially considering the fact that lower levels of government have a crucial impact on policies regarding transport quality and transport instruments. When citizens in Norway were asked about the most important issue for their vote in the most recent local election, for example, land-use, toll roads and transportation were ranked as the most important issues together with schools, environment and amalgamation issues. ${ }^{1}$

The article therefore aims at shedding light on why citizens are satisfied with governmental performance by including citizens' viewpoints on the use of restrictive instruments, as well as citizens' evaluation of transport quality. In doing so, the article responds to the call from Marsden and Reardon (2017) who criticize the 'technical-rational model within the transportation literature' while important questions, such as for instance political legitimacy, have largely been ignored.

The remainder of the article is structured as follows. Section 2 provides a literature review of factors influencing satisfaction with democracy. Explanatory factors identified in the literature are then used to develop a set of hypotheses. Literature regarding policy instruments is also included. In Section 3 the dataset used to address the hypotheses is then presented. Ordinary least squares regression and mediation analysis following Imai et al. (2011) are used to analyze mechanisms explaining variation in satisfaction with democracy. Finally, the last section discusses the findings and implications from the analysis.

\section{Literature}

Political legitimacy has deep roots within political philosophy (e.g. Hobbes, 1994; Mill, 1998; Rawls, 1971; Kant, 1999; Weber, 1978) yet it is a concept difficult and problematic to define (Rothstein, 2009:312). ${ }^{2}$ In general, political legitimacy is multi-dimensional in nature (Beetham, 1991). This was famously exemplified in Abraham Lincoln's Gettysburg address when he coined

\footnotetext{
1 The question was the following: "Could you mention the most important issue for personally when you voted in the municipal election this year?”. The top eight issues were the following: Schools $(9 \%)$, environment $(6 \%)$ transportation (5\%), municipal amalgamation (5\%), care for the elderly $(4 \%)$, health and social welfare $(4 \%)$, economy, taxes and toll roads (4\%), land-use/city development (4\%). $\mathrm{N}=1190$. The data are gathered from “Lokalvalgundersøkelsen 2015". Institute for Social Research and Statistics Norway made the data available but are not responsible for any of the analyses or interpretations.

${ }^{2}$ This is not the place for a more comprehensive account of developments regarding political legitimacy. For interested readers, see e.g. Beetham (1991), Beetham and Lord (1998), Habermas (1979), Dahl (1989), Norris (1999). With reference to (political) legitimacy Beetham (1991:15-16), for instance, state that "power can be legitimate to the extent that (i) it conforms to established rules, (ii) the rules can be justified by reference to beliefs shared by both dominant and subordinate, and (iii) there is evidence of consent by subordinate to the particular power relation.
} 
the well-known 'government of the people, by the people, for the people'. He thereby illustrated three dimensions of political legitimacy.

Within the literature on political legitimacy, David Easton's work (1965) is a common theoretical and analytic starting point for many. In this work Easton distinguishes three forms of political support: support for the political community, regime and authority respectively. This classification highlights the multi-dimensional aspect of political legitimacy based on what is often referred to as specific and diffuse support. Specific support refers to support for a particular government, party, politician, decision or actions, while diffuse support refers to support for the political system more generally as, for instance, the norms and rules found in that particular country or municipality. Dalton (1999) has later extended this operationalization of political evaluation into five categories; political community, regime principles, regime performance, regime institutions and political actors. Table 1, which in large part is based on the work of Norris (1999), illustrates how the different categories are defined and operationalized.

These levels can be understood as a scale of citizens evaluation of political support along an axis varying from specifictodiffuse support (Norris, 1999). 'Political community' and 'regime principles' are factors representing more abstract or diffuse support of democratic ideals and democratic principles. One typical way to operationalize 'regime principles' is e.g. pose the following statement and ask for respondent's agreement: "Democracy has it weaknesses but is better than any other form of government". Support for 'political actors', on the other hand, involves an evaluation of e.g. specific politicians or a government. The implications of experiencing a loss in public support are thus expected to vary greatly between these different dimensions (Peffley and Rohrschneider, 2014). Experiencing a loss in citizens' evaluation of democratic ideals can be grave since citizens might require constitutional reforms or accept of new forms of government. Experiencing a loss of public support for a particular government, on the other hand, can be less severe inasmuch as elections for example may offer an opportunity for changes in the government.

Support for democratic values and principles have traditionally been strong in the Nordic countries (Dahlberg et al., 2015). Thus, it is less likely that the nature of local transportation policies will have a significant impact on support for the principles of democracy. Similarly, transportation policies are expected to have low influence on general feelings of belonging to the local community. Use of restrictive instruments and perceived quality of transport may nonetheless constitute important factors for evaluating governmental performance and thereby satisfaction with how local democratic processes functions (Peffley and Rohrschneider, 2014). In terms of the model displayed in Table 1, this implies assessing regime performance.

'Satisfaction with democracy' is a widely used indicator for analyzing regime performance (cf. Norris, 1999; Linde and Ekman, 2003; Leiter and Clark, 2015; Hobolt, 2012; Huang et al., 2008; Curini et al., 2012; Wagner et al., 2009; Armingeon and Guthmann, 2014; Sanders et al., 2014; Anderson and Guillory, 1997; Blais and Gélineau, 2007; Aarts and Thomassen, 2008). There is, however, disagreement about its exact meaning and interpretation. On the one hand Canache et al. (2001) argue that satisfaction with de-mocracy measures multiple dimensions of political support and that the question is highly sensitive to differences across nations and individuals. Linde and Ekman (2003), on the other hand, argue that satisfaction with democracy measures the level of support for the way democracy works in terms of performance rather than measuring support for input features such as democratic principles compared to nondemocratic forms of government, or satisfaction with specific actors. It is this latter interpretation which the present article aims at measuring. 
Table 1. Conceptualization of political support (based on Norris, 1999:10)

\begin{tabular}{|l|l|l|l|}
\cline { 3 - 4 } & Object of support & Definition & Common operationalization \\
\cline { 2 - 5 } & Political community & $\begin{array}{l}\text { Often refers to attachment to the political } \\
\text { community being either the nation or } \\
\text { community }\end{array}$ & $\begin{array}{l}\text { Feclings of belonging to the community, } \\
\text { feclings of pride or identity }\end{array}$ \\
\cline { 2 - 5 } & Regime principles & $\begin{array}{l}\text { Refer to the democratic values and basic } \\
\text { democratic principles for the political } \\
\text { system }\end{array}$ & $\begin{array}{l}\text { Agrecments on specific values or question } \\
\text { about democracy being the preferred form of } \\
\text { governance }\end{array}$ \\
\cline { 2 - 5 } & Regime performance & $\begin{array}{l}\text { Support for how the political system } \\
\text { functions in practice }\end{array}$ & $\begin{array}{l}\text { Usually satisfaction with how democracy } \\
\text { works in practice }\end{array}$ \\
\cline { 2 - 5 } & Regime institutions & $\begin{array}{l}\text { Attitudes towards e.g. political parties, } \\
\text { government, parliament, police, the legal } \\
\text { system }\end{array}$ & $\begin{array}{l}\text { Questions tapping satisfaction with the } \\
\text { various institutions }\end{array}$ \\
\cline { 2 - 5 } & Political actors & $\begin{array}{l}\text { Specific support for politicians or political } \\
\text { actors }\end{array}$ & $\begin{array}{l}\text { Evaluations of particular leaders, politicians, } \\
\text { governments or presidents }\end{array}$ \\
\hline
\end{tabular}

\subsection{Determinants of satisfaction with (local) democracy}

Two standard models of regime support, input and output models respectively, are used as a frame of reference for addressing the research question. The input model focuses on democratic processes and institutions (Dahl, 1989; Easton, 1957, 1965) while the output model refers to the importance of policy output and policy outcome for political support (Rothstein, 2009; Magalhães, 2014; Dahlberg et al., 2015; Scharpf, 1999).

\subsubsection{The input (procedural) model of satisfaction with democracy}

One important dimension explaining satisfaction with democracy is related to democratic processes (Lijphart, 1999; Bernauer and Vatter, 2012). Democratic content or discontent is connected to citizens' evaluations of being represented in the political arena and having their voices heard (Norris, 1999). Citizens need to regard political processes and the political system as fair and honest (Peffley and Rohrschneider, 2014). The legitimacy of the political system is likely to be reduced if citizens feel that the political institutions do not represent their views or if they perceive their political representatives to be dishonest or incompetent. This aspect is captured by analyzing whether citizens think their views are well represented by politicians and whether citizens evaluate politicians as being honest and fair. Taken together, the literature suggests the following hypotheses:

H1. Individuals having confidence in politicians are more likely to be satisfied with how local democracy works.

H2. Individuals who think that the city council represents what people think are more likely to be satisfied with how local democracy works.

\subsubsection{The output (performance) model of satisfaction with democracy}

Several authors have likewise documented a relation between better performance and more positive evaluations of democracy, although there is no agreement on how performance should be measured. Performance is a multi-dimensional concept which en-compasses both political and economic aspects. While most articles analyzing the effect of governmental performance use economic variables such as the rate of unemployment, inflation and economic growth, some authors also link performance to issues as political salience and level of corruption (Bowler and Karp, 2004; Leiter and Clark, 2015). 
Local authorities in Scandinavia enjoy strong local autonomy (Loughlin et al., 2012) and have considerable influence on transport and land-use issues. Among other things municipals are responsible for local roads, parking policies and land-use development while regional authorities are responsible for public transport services and regional roads. ${ }^{3}$ Local authorities consequently play a crucial role when it comes to the adoption of (restrictive) instruments influencing the quality of transport within the region, as well as the prioritization of infrastructure projects. It is therefore possible to distinguish between general and specific performance at the local level. General performance is linked to how citizens evaluate the overall quality of services in the municipality (Erkel and Meer, 2016; Rohrschneider, 2005) while specific support is in the present case linked to how citizens evaluate the local transport accessibility and municipal land-use development.

The relevant hypotheses are consequently:

H3. Individuals satisfied with the overall quality of services are more likely to be satisfied with local democracy (general performance).

H4. Individuals satisfied with the quality of transport are more likely to be satisfied with local democracy (specific performance).

\subsubsection{The role of instruments for satisfaction with local democracy}

The choice of policy instruments is a vital part of local governance performance, and instruments are not politically neutral

(Peters, 2002; Salamon, 2002). Potentially, therefore, the adoption and implementation of a given instrument can have significant consequences for perceived political performance and hence political legitimacy (Schneider and Ingram, 1990; Salamon, 2002).

From such a viewpoint the selection and use of specific policy instruments may be subject to what in the literature is identified as ideological congruence between citizens and politicians (Kim, 2009). Previous research has largely used the left-right scale as an indicator for analyzing congruence. But as Stecker and Tausendpfund (2016) note, this provides only an incomplete understanding of political preferences and ideological congruence. Policy preferences are far more differentiated and multi-dimensional phenomenon (Stecker and Tausendpfund, 2016). Different issues are important for different people and the left-right scale does not fully capture the political differences across all policy fields.

In this respect support for local toll roads provide a better indicator of how perceptions of specific policy instruments may influence satisfaction with local democracy. In Norway most citizens are affected by toll roads since a majority own cars (Christiansen et al., 2016) and hence are subject to paying tolls when using their cars. The largest cities have in particular had a relatively long-term history of congestion pricing and use of toll rings. In Bergen, for instance, the first toll cordon system was established in 1986 (Engebretsen et al., 2017) while in Oslo and Trondheim tolls were introduced in 1990 and 1991 respectively (Bekken and Osland, 2005). These toll cordon systems have subsequently been expanded several times with the creation of new toll stations and new rates to finance local roads and public transport. These developments have been a highly salient topic of public debate. They are regularly discussed in local newspapers and between local political parties. Thus, most people living in these cities are likely to have a reasonably well informed opinion on the matter. Arguably, therefore, road tolls represent a policy area that is well suited for an investigation of the consequences of controversial long-term policy choices.

\footnotetext{
${ }^{3}$ However, the national level is responsible for national roads, train infrastructure and train services.
} 
I therefore hypothesize the following:

H5. Individuals opposing toll roads are less likely to be satisfied with democracy.

\subsubsection{Other bypotheses identified in the literature}

In a somewhat related fashion a winner versus loser hypothesis states that citizens who voted for the winning side are more inclined to be satisfied with democracy since they are more likely to see policy choices as being more in keeping with their own political preferences. There are numerous studies documenting such a relationship (Curini et al., 2012; Chang et al., 2014; Blais and Gélineau, 2007; Anderson and Guillory, 1997; Anderson and Tverdova, 2001; Singh et al., 2012; Reher, 2016). Winners also express higher trust of parties or politicians that are in government (Blais and Gélineau, 2007). This leads to the following hypothesis:

H6. Individuals feeling attachment to the parties in government are more likely to be satisfied with local democracy.

Lastly, previous research has not found a clear effect of education. It can potentially have both positive and negative effects. For instance, education can presumably generate skepticism towards specific political answers and policies, but it can also increase citizens' knowledge and appreciation of the complicated nature that characterize many of today's societal challenges. Political interest may also be associated with satisfaction with democracy (Sanders et al., 2014). Just as for education, the same logic applies with respect to being politically interested or being informed on local politics through reading local news. Mass media can frame issues in a negative or sensational way, but they can also increase readers' understanding of local politics and make them better equipped to assess local governmental performance. This leads to two contrasting hypotheses:

H7a. Individuals who are informed and interested in politics are more likely to be satisfied with local democracy.

H7b. Individuals who are informed and interested in politics are less likely to be satisfied with local democracy.

Fig. 1 provides an illustration of the analytic model used in the next section. The figure is a summary of the hypotheses identified in the literature review and the relationships between the variables as they are usually are treated in the literature. Four main determinants of satisfaction with democracy described by $\mathrm{H} 1$ to $\mathrm{H} 7$ are included and, in addition, three general predictors (age, sex and education) are included among the individual and contextual factors as control variables. The figure thereby illustrates a straightforward model for an analysis of the direct effects and functions as a point of departure for the regressions reported in Table $3{ }^{4}$

Figure 1. Model specification for direct effects.

\footnotetext{
${ }^{4}$ Although it is likely that several of the independent variables could influence other dimensions of political support, this article is limited to the effect on regime performance. Moreover, while theoretically interesting, the dataset does not allow for consideration of whether the dependent variable (satisfaction with how local democracy works) influences the other dimensions of political support. In Section 4.3, a more complicated model is used for analyzing mediation effects in order to account for interaction between the input and output aspects of political support.
} 


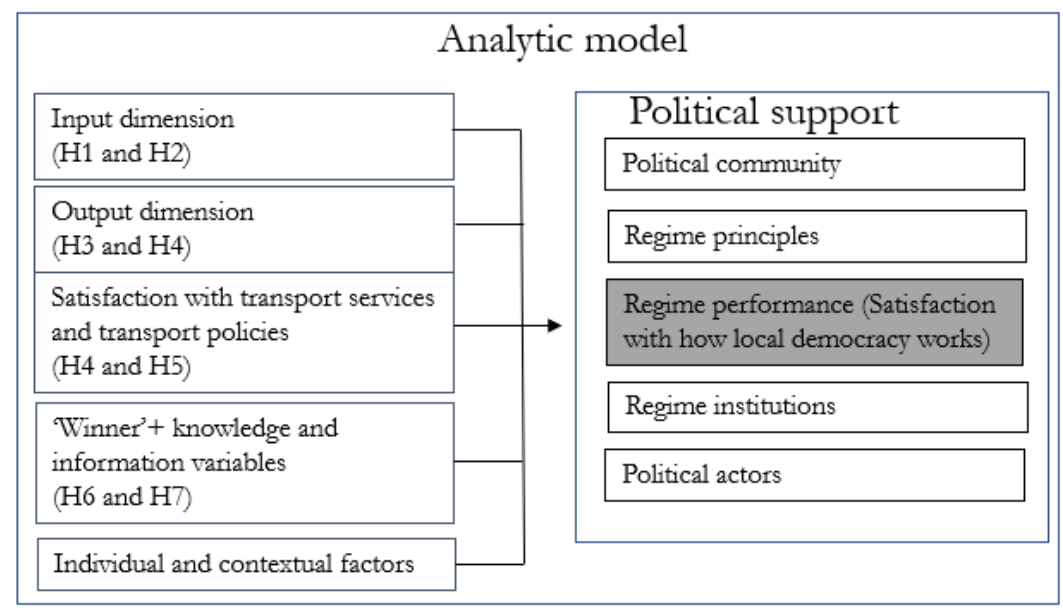

\section{Data and measurement}

Citizens in the three largest cities in Norway Oslo, Bergen and Trondheim, were recruited through a representative web panel. The questionnaire measured attitudes towards how local democracy works and captured the inhabitants' views on local governments performance and quality, as well as views on the use of selected transportation policy instruments. A total of 6443 persons aged 18 or above were invited to participate during March of 2017 and 48\% (3072 persons) completed the survey. The sample(s) were later weighted for age, gender and geography. The appendix provides information about the questions included in the analysis and the coding of each variable.

\subsection{Dependent variable}

The respondents were asked 'How satisfied or dissatisfied are you with the way in which local democracy works in your municipality'.

\subsection{Independent variables}

First, to analyze the input dimension, respondents were asked to provide answers to three statements regarding their views on politicians' responsiveness, competence and integrity: "Politicians take into account the inhabitants' viewpoints", "Politicians are competent people knowing what they are doing" and "Politicians in my municipality set aside their personal interests when taking political decisions". Factor analysis produced a unidimensional component explaining $80 \%$ of the variance in the set of items (Cronbach's alpha $=0.80$ ). In addition, a question about how well "the city council represents what people think" was also included as a separate variable to capture political representativeness.

Second, two variables are used for analyzing the governmental output dimension. Respondents were asked to state on a ten-point scale whether they were satisfied or not satisfied with the way the local authority has handled all types of local challenges. They were also asked to assess how satisfied they were with municipal services in general: "The municipal is responsible for different areas within health care, education, culture, sport facilities and transport. All in all, do you think the municipal services are very good, pretty good, less good or not good.".

Third, the questionnaire included questions focusing specifically on support for local road tolls in the region, as well as satisfaction with quality of various aspects within transport. Respondents were allowed to answer 'don't know' on the majority of these questions.

Fourth, a variable showing in which municipality the respondents lived was also included in order to capture contextual differences. The model also includes questions about how well respondents felt they were about local politics and how often they read local or regional news. Socio-demographic variables included information about age, sex and education. 
Lastly, individuals supporting a party in power are classified as "winners" while those supporting other parties, or who did not support any political party at all, are classified as "losers".

\section{Results}

\subsection{Descriptive overview of satisfaction with democracy at the local and national level}

Table 2 shows the distributions of satisfaction with how local democracy works in the three municipalities of interest, as well as a general development on satisfaction with democracy for all municipalities in Norway between 2007 and 2011. Support for local road tolls in the three selected cities is also shown. 
Table 2. Developments and contextual differences for satisfaction with democracy and acceptance of road tolls

\begin{tabular}{|c|c|c|c|c|c|c|}
\hline & & Oslo (2017) & Bergen (2017) & $\begin{array}{l}\text { Trondheim } \\
\text { (2017) }\end{array}$ & $\begin{array}{l}\text { Local } \\
\text { democracy } \\
(2007)^{5}\end{array}$ & $\begin{array}{l}\text { Local democracy } \\
\text { (2011) }\end{array}$ \\
\hline \multirow{5}{*}{$\begin{array}{l}\text { Satisfaction with } \\
\text { local democracy }\end{array}$} & Not at all & 7 & 7 & 6 & 2 & 2 \\
\hline & Not very & 20 & 31 & 23 & 16 & 12 \\
\hline & Fairly & 67 & 58 & 61 & 75 & 71 \\
\hline & Very & 7 & 5 & 10 & 6 & 15 \\
\hline & $\mathrm{N}$ & 896 & 964 & 730 & 657 & 1027 \\
\hline \multirow{6}{*}{$\begin{array}{l}\text { Support for local } \\
\text { toll roads }\end{array}$} & Very negative & 14 & 15 & 16 & & \\
\hline & Quite negative & 16 & 21 & 21 & & \\
\hline & $\begin{array}{l}\text { Neither positive } \\
\text { nor negative }\end{array}$ & 27 & 28 & 27 & & \\
\hline & Quite positive & 30 & 25 & 27 & & \\
\hline & Very positive & 14 & 10 & 9 & & \\
\hline & $\mathrm{N}$ & 990 & 1078 & 816 & & \\
\hline
\end{tabular}

If we look first at the right side of the table containing the distribution of satisfaction with local democracy across all municipalities, it is evident that the share of people who are satisfied with the way local democracy works has increased between 2007 and 2011. It is important to note in this regard that the local election in 2011 took place only a few weeks after the terrorist attack in Oslo and at Utøya on July 22. Trust in political institutions and politicians increased after the attack (Bergh and Christensen, 2013). Compared to the national average in 2011, however, citizens in Oslo, Bergen and Trondheim are clearly more dissatisfied in 2017. Unfortunately there are no data for analyzing how satisfaction with local democracy has on average developed since 2011. In general, however, the share of citizens being satisfied is nonetheless higher compared to the average level in most other European countries (Sanders et al., 2014; Rose and Pettersen, 2009a).

The table also illustrates the importance of contextual differences when it comes to support for local toll roads. Despite long experiences with toll roads, the population is rather split in all three municipalities. Between 30 and $37 \%$ are negative, while the share of people that are positive varies between 35 and $44 \%$. The share of people who are negative is higher in Bergen and Trondheim than it is in Oslo. Consequently, there are differences in the level of support between the three municipalities.

It is beyond the scope of this article to go into great detail explaining these differences in support for tolls in the three cities. The aim here is to analyze how lack of support potentially influences satisfaction with local democracy regardless of the reasons for being positive or negative. Within the literature on acceptance of public policies, however, attitudes to congestion pricing is linked to a variety of factors (see, for instance, Eliasson, 2017). At least three key contextual differences may partly explain the variation in support between the cities: (1) the level of congestion, (2) the general costs of tolls, and (3) when changes in the toll cordon system occurred. Oslo has relatively more congestion than Bergen and Trondheim. This may well have influenced an understanding of the need for tolls to regular traffic and to finance transportation infrastructure.

${ }^{5}$ Data regarding satisfaction with democracy in 2007 and 2011 are gathered from "Lokalvalgundesøkelsen 2007" and "Lokalvalgundersøkelsen 2011" respectively. The Institute for Social Research and Statistics Norway made the data available, but are not responsible for any of the analyses or interpretations. 
In addition, Trondheim introduced new toll stations within the city in 2014, and Bergen had an increase in toll charges in 2012. Raising the tolls can potentially decrease the level of public support inasmuch as the costs for people increase. The same argument applies to the cost for passing the toll cordon. In 2017, the price for driving through a toll station was 25 NOK (49 NOK during rush hours) in Bergen, 9 NOK (22 NOK during rush hours) in Trondheim and 34 NOK in Oslo. The level of toll is therefore significantly lower in Trondheim compared to the other cities.

In the following further empirical analyses are divided into two sections. In the first section, which is based on Fig. 1, variation in the level of satisfaction with local democracy is analyzed controlling for other well-known explanatory factors already identified in the literature: This is done by means of ordinary least square regression. The second part analyses the indirect effects and proportions of the total effects being mediated through the input and output dimensions.

\subsection{Model results - direct effects}

Five models are presented here. The first includes individual, contextual and knowledge variables (control, H6 and H7), the second adds variables concerning the input dimension for political legitimacy (H1 and H2), the third model includes the govern-mental output dimension (H3 and $\mathrm{H} 4$ ), the fourth adds specific variables about the use of instruments and quality of services within the transport sector ( $\mathrm{H} 4$ and $\mathrm{H} 5)$, while the fifth model includes all variables. The regression analyses make it possible to compare the relative importance of variables added at each step by comparing differences in the adjusted $\mathrm{R}$ square.

Looking first at model 1 in Table 3, one can see that individual factors have the expected effect on satisfaction with democracy. The model also provides support for the winner and loser hypothesis; citizens who support the parties in a majority coalition are more likely to be satisfied with how local democracy works (H6). However, in contrast to existing literature, the model does not show any effect of feeling well informed about local politics or having higher education. In other words, neither $\mathrm{H} 7 \mathrm{a}$ nor $\mathrm{H} 7 \mathrm{~b}$ receives support in the analysis.

Turning to the contextual factors, residents in Bergen are less satisfied with democracy. This can be related to the argument from Leiter and Clark (2015) and Bowler and Karp (2004) regarding the importance of valence with respect to the impact of governing parties on satisfaction with democracy. Local politics in Bergen has been more subject to instances of political turmoil compared to the other municipalities. ${ }^{6}$ Potentially this can partly explain differences in local satisfaction. The size of the effects, however, is in general small. The most important factors in model 1 are age (-0.14) and being classified as a winner (0.24).

In model 2, which serves to highlight the input dimension, all new variables are statistically significant. For citizens who agree with the statement that the city council represents what people think well satisfaction with democracy is greater (by a standard deviation of 0.15 ) than people who disagree. The index regarding attitudes about politicians also has a clear impact. Satisfaction with local democracy increases when politicians are regarded as competent and sensitive for citizens' viewpoints. In fact, in all models, the index concerning politicians has the largest impact on satisfaction with local democracy. An increase in R square from 0.10 to 0.39 clearly indicates the importance of input legitimacy for democratic satisfaction compared to individual and contextual factors. These results are thus in line with $\mathrm{H} 1$ and $\mathrm{H} 2$.

\footnotetext{
${ }^{6}$ For instance, the former mayor was investigated for corruption. There have also been fierce discussions about future policies for light rail and whether the municipality should introduce congestion charging. See Pellegata and Memoli (2018). Corruption and satisfaction with democracy: the conditional role of electoral disproportionality and ballot control. European Political Science Review, 1-24. for an overview of corruption and its relationship to satisfaction with democracy.
} 
Turning to model 3, we can furthermore look at how the governmental output dimension influences satisfaction with democracy. Two variables are meant to capture the output dimension. The first variable measures the effect of citizens being satisfied with how local authorities have handled local challenges. The second variable measures the effect of being dissatisfied with municipal services in general. Moving one standard deviation with respect to being satisfied with how local authorities have handled local challenges increases satisfaction with democracy by 0.43 standard deviations, while being dissatisfied with municipal services reduces satisfaction by 0.14 . The size of these effects and the increase in $\mathrm{R}$ square demonstrate that the output dimension is a key factor for explaining satisfaction with local democracy. Thus, as expected, the results support $\mathrm{H} 3$.

Model 4 expands the perspective to analyze the effects of being positive or negative towards use of a restrictive transportation policy instrument, as well as satisfaction with two transportation issues. In this case the model shows a relationship between support for a restrictive instruments and satisfaction with local democracy. Citizens being negative towards tolls are significantly more dissatisfied with local democracy. This confirms the assumption regarding a relationship between the choice of policy instruments and governmental legitimacy. The size of these effects, however, is rather low (0.15). In addition, model 4 shows how satisfaction with transportation policies influence satisfaction with democracy. Here the model demonstrates that transport services are relevant and citizens who are less satisfied with quality are less satisfied with democracy. The results then support $\mathrm{H} 4$ and $\mathrm{H} 5$.

Lastly, model 5 includes all variables. Just as in the previous models, the analysis supports hypothesis 1-6. The coefficients have the same direction and have the same significance levels. This serves to confirm that individual factors, in combination with the input and output dimensions, as well as specific transport issues, influence satisfaction with democracy. However, the model also shows that there are differences regarding the relative effect of some variables. Especially factors measuring the output and input dimensions, as well as specific transport factors, are reduced when all variables are included (model 5). This indicates that these factors are correlated not only with the dependent variable, but also with one or more of the other independent variables. It can thus be an empirically argument for conducting the mediation analysis in Section 4.3.

In model 5 an interaction term is also added since it possible that the effect of being dissatisfied with the local toll cordon system is dependent on how satisfied individuals are with the way local politicians are perceived to handle local challenges in general. Previous research has for instance documented that acceptance of some policy instruments is related to their perceived effects (Börjesson et al., 2012). In the present case the results in model 5 indeed show that the potential negative effects of opposing the local toll cordon system can partly be offset if citizens are satisfied with the way politicians handle local challenges more generally.

When all variables are included in the model, the adjusted $\mathrm{R}$ square increases to 0.46 . It is difficult to compare the adjusted $\mathrm{R}$ square with results in other studies due to differences in approach and the variables used. The bulk of studies have focused on differences in satisfaction with democracy between countries at the national level and not on the local level. The explained variance in the present case, however, is relatively high compared to some studies (Anderson and Guillory, 1997) and is at roughly the same level compared to others (Armingeon and Guthmann, 2014).

Lastly, some authors have argued that democratic effectiveness is more important for democratic satisfaction than ideological congruence on the input side (Dahlberg and Holmberg, 2014). The models in this paper do not support such a conclusion. The differences in R2 rather suggest an 
almost equal importance between the input and output dimension for satisfaction with democracy. 
Table 3. Direct effects on satisfaction with local democracy. OLS regression. Standardized B (std.error).

\begin{tabular}{|c|c|c|c|c|c|c|c|c|c|c|}
\hline \multirow{2}{*}{$\begin{array}{l}\text { Variables } \\
\text { Constant }\end{array}$} & \multicolumn{2}{|c|}{$\begin{array}{c}\text { Model } 1 \text { (individual and } \\
\text { contextual factors) }\end{array}$} & \multicolumn{2}{|c|}{$\begin{array}{c}\text { Model } 2 \text { (individual } \\
\text { and contextual }+ \\
\text { input dimension) }\end{array}$} & \multicolumn{2}{|c|}{$\begin{array}{c}\text { Model } 3 \text { (individual } \\
\text { and contextual }+ \\
\text { output dimension) }\end{array}$} & \multicolumn{2}{|c|}{$\begin{array}{l}\text { Model } 4 \text { (individual } \\
\text { and contextual + } \\
\text { transport issues) }\end{array}$} & \multicolumn{2}{|c|}{$\begin{array}{l}\text { Model } 5 \text { (all } \\
\text { factors) }\end{array}$} \\
\hline & & & & & & & & & & \\
\hline Age & $-0.14(0.00)$ & $* * *$ & $-0.09(0.00)$ & $* * *$ & $-0.12(0.00)$ & $* * *$ & $-0.08(0.00)$ & $* * *$ & $-0.09(0.00)$ & *** \\
\hline Sex $(1=$ male $)$ & $-0.02(0.03)$ & & $0.01(0.02)$ & & $-0.01(0.02)$ & & $0.01(0.02)$ & & $0.02(0.02)$ & \\
\hline Education & $0.04(0.3)$ & * & $-0.01(0.02)$ & & $0.01(0.02)$ & & $0.03(0.03)$ & . & $0.00(0.02)$ & \\
\hline Bergen $(\mathrm{Oslo}=$ reference category $)$ & $-0.07(0.03)$ & $* * *$ & $-0.05(0.03)$ & $* *$ & $-0.07(0.03)$ & $* * *$ & $\mid-0.03(0.03)$ & & $-0.04(0.03)$ & $*$ \\
\hline Trondheim (Oslo=reference category) & $-0.00(0.04)$ & & $-0.01(0.03)$ & & $-0.04(0.03)$ & $*$ & $0.00(0.03)$ & & $-0.03(0.03)$ & \\
\hline Reading local news (H7a/b) & $0.01(0.04)$ & & $0.00(0.03)$ & & $\mid-0.00(0.03)$ & & $0.00(0.03)$ & & $-0.00(0.03)$ & \\
\hline Political informed (subjectively) $(\mathrm{H} 7 \mathrm{a} / \mathrm{b})$ & $0.07(0.03)$ & $* * *$ & $0.01(0.02)$ & & $0.03(0.02)$ & * & $0.06(0.03)$ & $* * *$ & $0.02(0.02)$ & \\
\hline Winner (H6) & $0.26(0.03)$ & $* * *$ & $0.08(0.02)$ & $* * *$ & $0.12(0.02)$ & $* * *$ & $0.17(0.03)$ & $* * *$ & $0.06(0.02)$ & *** \\
\hline Politicians (H1) & & & $0.46(0.02)$ & $* * *$ & & & & & $0.28(0.02)$ & *** \\
\hline City council represents what people think well (H2) & & & $0.15(0.03)$ & $* * *$ & & & & & $0.11(0.02)$ & *** \\
\hline Satisfied with handling of local challenges $(\mathrm{H} 3)$ & & & & & $0.43(0.00)$ & $* * *$ & & & $0.17(0.00)$ & *** \\
\hline Dissatisfied with municipal services (H4) & & & & & $-0.14(0.03)$ & $* * *$ & & & $-0.04(0.03)$ & * \\
\hline Dissatisfied with "city-development” (H4) & & & & & & & $-0.27(0.03)$ & $* * *$ & $-0.13(0.03)$ & $* * *$ \\
\hline Dissatisfied with car accessibility (H4) & & & & & & & $-0.17(0.03)$ & $* * *$ & $-0.06(0.03)$ & $* * *$ \\
\hline Dissatisfied with tolls (H5) & & & & & & & $-0.15(0.03)$ & $* * *$ & $-0.12(0.07)$ & $* *$ \\
\hline Satisfied with handling of local challenges*toll roads (H5) & & & & & & & & & $0.09(0.01)$ & $*$ \\
\hline Adjusted R square & 0.11 & & 0.39 & & 0.36 & & 0.27 & & 0.46 & \\
\hline $\mathrm{N}$ & 2548 & & 2455 & & 2470 & & 2476 & & 2337 & \\
\hline
\end{tabular}




\subsection{Mediation analysis}

In the previous section, the direct effects of different independent variables for satisfaction with local democracy were analyzed. In this section, the aim is to gain more insights into how transport policies and transport quality can influence satisfaction with democracy by identifying mechanisms. Following Imai et al. (2011), a mediation approach is used to investigate how transport factors may potentially have an impact in both the input and output models used to explain variation in satisfaction with democracy.

Empirical results presented in Table 3 suggested a mediation effect. But every bit as important one can theoretically argue that perceived transport quality and support for selected transport policy instruments are relevant in the input and output models used in this article. Easton (1957), for example, wrote about the feedback mechanisms that are likely to exist between the input and output dimensions of support for a political system. In Fig. 2 this would imply that citizens opposing local toll roads could be more inclined to think that politicians are less competent or that politicians are less likely to consider the inhabitants' viewpoints. Politicians could also be blamed if citizens are not pleased with transport accessibility or if they disagree with local landuse development policies. People opposing local toll roads could also be less satisfied with the perceived character of policy decisions by arguing that tolls are unfair, inefficient or unnecessary for solving local challenges. Being dissatisfied with the quality within different transport issues could also naturally influence citizens' evaluation of governmental performance. Consequently, the subsequent analysis will focus on mediation effects on both dimensions.

Figure 2 illustrates the logic of the mediation analysis. Results presented previously in Table 2 documented the direct effect of each variable. By comparison, mediation analysis serves to identity mediated (indirect) effects. In the following model 5 from Table 3 is used in all of the analyses, and the results presented are limited to the average causal mediation effect (ACME), the total effect and the proportion mediated effect for each transport variable.

Figure 2. Model specification for direct and indirect effects.

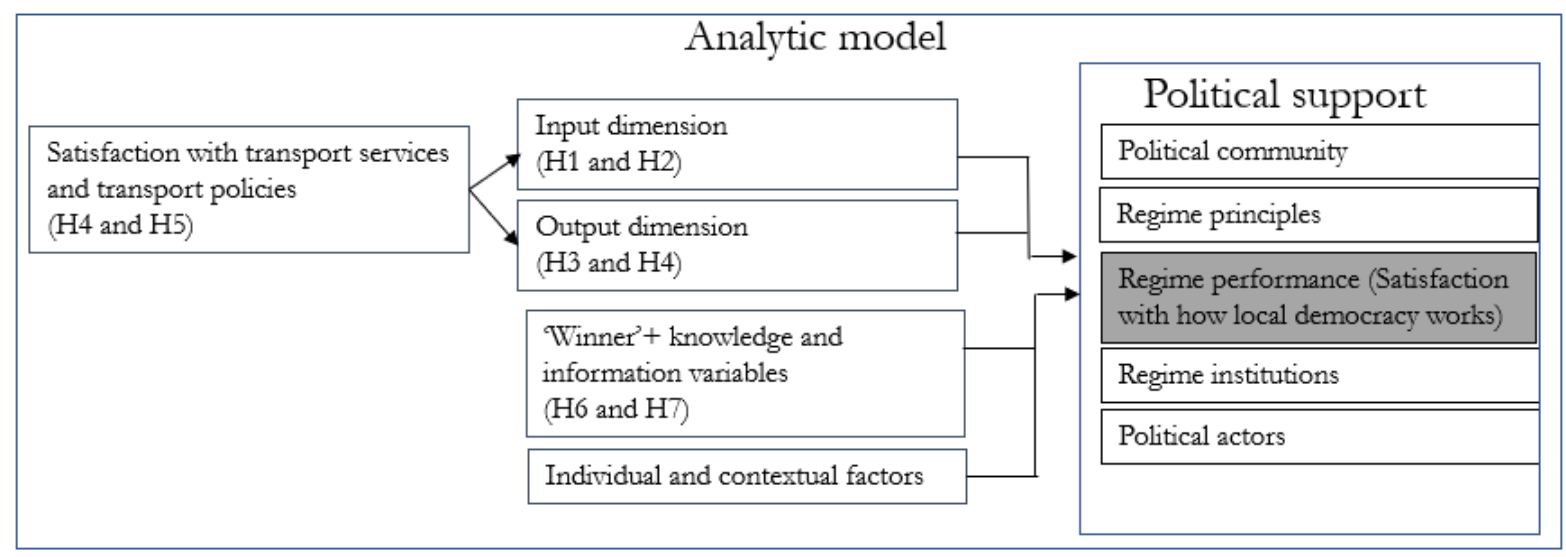

Results found in Table 4 suggest a mediation effect (ACME) for each independent variable. As is evident, being dissatisfied with tolls or being dissatisfied with the quality of services for car accessibility and city development reduces satisfaction with local democracy, and it does so via both the input and output dimensions. The results therefore indicate a more complex relationship between the variables since they imply pathways in addition to those reflected by the simple direct effects. In other words, the results suggest that transport policies and perceived transport quality influence satisfaction with how local democracy works both directly and indirectly. In particular, as the findings in Table 4 make apparent, they indirectly influence two of the factors having the relatively largest effect on the dependent variable. The size of the effects, however, is low, varying between an average of 0.01 and 0.04 . 
Coefficients found in the columns for proportion mediated furthermore show the importance of the average causal mediating effects by analyzing how much of the total effect is transmitted via the mediators. Thus, when comparing the relative importance of the mediating effects, the table shows that, on average, the proportion mediated varies between 0.10 and 0.47 . Not being satisfied with tolls has the largest proportion mediated, but this is in large part related to the lower total effect of this variable.

Table 4. Mediation analysis ${ }^{7} . N=2354$

\begin{tabular}{|c|c|c|c|c|c|c|}
\hline & \multicolumn{3}{|c|}{ Politicians } & \multicolumn{3}{|c|}{$\begin{array}{l}\text { Satisfied with handling of local } \\
\text { challenges (output) }\end{array}$} \\
\hline & ACME & $\begin{array}{l}\text { Total } \\
\text { effect }\end{array}$ & $\begin{array}{l}\text { Prop. } \\
\text { mediated }\end{array}$ & ACME & $\begin{array}{l}\text { Total } \\
\text { effect }\end{array}$ & $\begin{array}{l}\text { Prop. } \\
\text { mediated }\end{array}$ \\
\hline $\begin{array}{l}\text { Not satisfied } \\
\text { "city- } \\
\text { development" }\end{array}$ & $-0.03^{* * *}$ & $-0.24 * * *$ & $0.13^{* * *}$ & $-0.03^{* * *}$ & $-0.24 * * *$ & $0.14^{* * *}$ \\
\hline $\begin{array}{l}\text { Not satisfied car } \\
\text { accessibility }\end{array}$ & $-.04 * * *$ & $-0.14^{* * *}$ & $0.28^{* * *}$ & -0.01 & $-0.10^{* * * *}$ & $0.10^{* * *}$ \\
\hline $\begin{array}{l}\text { Not satisfied } \\
\text { with tolls }\end{array}$ & $-0.03^{* * *}$ & $-0.07 * *$ & $0.47 * *$ & $-0.02^{* * *}$ & $-.05^{*}$ & $.30^{*}$ \\
\hline
\end{tabular}

\section{Conclusion}

This article contributes to the literature by analyzing how restrictive instruments and perceived transport quality potentially influence political legitimacy at the local level. It consequently sheds some light on an issue that, according to Marsden and Reardon (2017) has been largely ignored. The results also contribute to the theoretical discussion about satisfaction with local democracy, what constitutes quality of government (Rothstein and Teorell, 2008), and how citizens evaluate governmental performance (Olsen, 2017). However, it is important to note that the analysis is solely limited to regime performance. The analysis does not take into account the full range of factors that constitute the other dimensions of political legitimacy.

Results from both regression and mediation analyses suggest a relationship between transportation policies and satisfaction with how democracy works at the local level. Introducing restrictive measures, such as toll roads, can decrease citizens' evaluations of both politicians, and their evaluation of governmental performance. Although the results suggest only small effects on satisfaction with local democracy, these results nevertheless underline the importance of understanding how citizens are affected by specific policy instruments, as well as showing that ideological proximity and performance are multi-dimensional aspects (see, for example Kim, 2009; Ezrow and Xezonakis, 2011; Stecker and Tausendpfund, 2016).

There are several policy and research relevant implications stemming from these results. First, they highlight the importance of keeping an eye on public support. Even though previous studies on congestion pricing have shown that the level of opposition is reduced after it has been implemented, this study illustrates that there still is a significant portion of the population who are negative despite long-term familiarity with road tolls. This is especially relevant when taking into consideration that citizens who are dissatisfied with regime performance might be more likely to call for radical changes (Bernauer and Vatter, 2012) or the policies may erode beliefs about democratic principles (Norris, 1999). The potential negative political consequences arising from disgruntled citizens, however, are de-batable. It can be argued that dissatisfied citizens strengthen democratic government insofar as they become more politically engaged (see Norris,

\footnotetext{
${ }^{7}$ Bootstrapping, with 1000 simulations, is used in the mediation analysis.
} 
1999). For instance, a new party in Norway, The peoples' movement against more tolls, for instance, aims at competing in the next local election in 2019. The party was first established in Stavanger - Norway's fourth largest city- because of decisions about increasing tolls and the introduction of congestion pricing. Such a development can be of increased importance inasmuch as all levels of government increasingly rely on tolls for financing infrastructure projects and for reaching policy goals aimed at reducing emissions from the transport sector. The Norwegian Parliament has developed a zero-growth target which means that there should be no growth in personal car traffic. The national government therefore requires that municipalities shall have zero-growth in personal car traffic if they are to receive co-financing for local transport infrastructure. Restrictive measures such as tolls and parking policies then become essential tools.

Second, this study gives some support to the claim that instruments influence the political support that government enjoys (Salamon, 2002). This is especially relevant considering the fact that some studies suggest that it can be difficult for citizens to evaluate political performance and policy outcomes based on which party is in office (Holbein and Dynes, 2018). Thus, holding local governments accountable through retrospective voting based on objective evaluation of what local government achieves is challenging. Policy instruments, on the other hand, are something which politicians, arguably, control to a larger degree. The toolbox within the field of transport, for instance, contains a multitude of options varying from tolls, congestion pricing, parking policies and land-use policies. These are policies that to varying degrees are visible and foster disagreement along the ideological spectrum. From such a perspective, alternative policy instruments may well constitute one factor influencing citizens' evaluations underlying public support. In this respect future studies might do well to consider how opposition to or support for a multitude of different instruments, both within and across various policy sectors, influence political legitimacy. If so it would then become possible to study how the accumulation of support and opposition towards different policy instruments influences political legitimacy.

Third, taking into account context and time, the analysis shows that the level of satisfaction with democracy and the support for restrictive instruments varies between the three selected municipalities. This indicates the necessity of thinking about local contexts when considering implementing restrictive measures. The impact on political legitimacy can be partly dependent on the level of resistance within the city at a specific point in time. It is possible, for instance, that the consequences for local and national satisfaction with democracy are larger immediately after they are implemented. The same logic may also apply to instances when authorities decide to increase the costs for passing toll stations. This means that it is not irrelevant when in an election circle, for example, authorities decide to implement toll roads or congestion pricing. However, it is important to note that implementing restrictive measures also can increase satisfaction with democracy insofar as governments are perceived to perform better in terms of e.g. ameliorating problems associated with emission or congestion. These results also underline the need for understanding strategies to increase acceptance (Eliasson and Jonsson, 2011).

Fourth, previous research has argued that legitimacy at lower levels of government influences legitimacy at higher levels (Vetter, 2007). From such a perspective the performance of local authorities is relevant for the national level. It is possible, for example, that opposition to local tolls may also have an impact on satisfaction with democracy at the national level. Such an argument illustrates the interdependence between different levels of government.

Fifth, empirically this article has analyzed the effect of two contrasting theoretical perspectives with respect to satisfaction with democracy - one perspective which emphasizes the importance of feeling represented and having competent politicians, a second which highlights the significance of governmental performance. The results provide support for both perspectives and are in line with the findings from (Dahlberg et al., 2015). Changes in explained variance 
indicates that both the input and output models contribute significantly to satisfaction with democracy.

Further research regarding these issues is necessary. This article uses cross sectional data for analyzing the relationship between specific policy instruments and satisfaction with democracy at the local level. The findings suggest a correlation between introduction of these instruments and satisfaction with democracy. The dataset used, however, unfortunately allows little room for using other research designs allowing for an analysis of causality. Further studies are therefore needed for evaluating the direction of causality between the variables. Explicating the causal relationship between political legitimacy and voter turnout or voting behavior would, for example, be especially useful in understanding the political implications of transportation policies for political legitimacy. Other studies could also use designs involving before and after implementation analyses of e.g. tolls, congestion pricing, parking policies or implementing carfree areas in order to make better claims about causal effects and to study the short-term consequences of introducing restrictive instruments. Studies could furthermore analyze the importance of issue priorities for evaluating governmental performance at both the local and the national level, go into further detail with respect to how citizens evaluate governmental performance, and analyze how a toll cordon system influences satisfaction with democracy for citizens living in surrounding municipalities affected by tolls. Many issues, in short, remain on the agenda for further research.

\section{Acknowledgement:}

I am grateful to professor Lawrence E. Rose at the University of Oslo for his invaluable comments. I also wish to thank Kåre Skollerud, Ove Langeland and two anonymous reviewers for their comments on earlier drafts of this article.

\section{Funding}

This work was supported by the Research Council of Norway for a project entitled "Changing commuting in large urban areas - identifying acceptable and effective measures (COMMUTE)' (249733/080). 


\section{References}

Aarts, K., Thomassen, J., 2008. Satisfaction with democracy: do institutions matter? Electoral Stud. 27, 5-18.

Albalate, D., Bel, G., 2009. What local policy makers should know about urban road charging: lessons from worldwide experience. Public Admin. Rev. 69, 962-974. Anderson, C.J., Guillory, C.A., 1997. Political institutions and satisfaction with democracy: a cross-national analysis of consensus and majoritarian systems. Am. Polit.

Sci. Rev. 91, 66-81.

Anderson, C.J., Tverdova, Y.V., 2001. Winners, losers, and attitudes about government in contemporary democracies. Int. Polit. Sci. Rev. 22, 321-338. Armingeon, K., Guthmann, K., 2014. Democracy in crisis? The declining support for national democracy in European countries, 2007-2011. Eur. J. Polit. Res. 53,

423-442.

Beetham, D., 1991. The Legitimation of Power. MacMillian, Hampshire.

Beetham, D., Lord, C., 1998. Legitimacy and the European Union. Longman, Essex.

Bekken, J.-T., Osland, O., 2005. An offer you can't refuse... On the establishment and development of Norwegian toll cordons. PIARC Seminar on Road Pricing with

Emphasis on Financing, Regulation and Equity, Cancun, Mexico. April, 2005, pp. 11-13.

Bemelmans-Videc, M.-L., Rist, R.C., Vedung, E.O., 2011. Carrots, Sticks, and Sermons: Policy Instruments and their Evaluation. Transaction Publishers, New

Brunswick.

Bergh, J., Christensen, D.A., 2013. Det norske lokaldemokratiet: En statusrapport. In: Bergh, J., Christensen, D.A. (Eds.), Et robust lokaldemokrati - lokalvalget i

skyggen av 22. juli 2011. Abstrakt forlag AS, Oslo.

Bernauer, J., Vatter, A., 2012. Can't get no satisfaction with the Westminster model? Winners, losers and the effects of consensual and direct democratic institutions on

satisfaction with democracy. Eur. J. Polit. Res. 51, 435-468.

Blais, A., Gélineau, F., 2007. Winning, losing and satisfaction with democracy. Polit. Stud. 55, 425-441.

Bowler, S., Karp, J.A., 2004. Politicians, scandals, and trust in government. Polit. Behav. 26, 271287.

Börjesson, M., Eliasson, J., Hamilton, C., 2016. Why experience changes attitudes to congestion pricing: the case of Gothenburg. Transport. Res. Part A: Policy Pract.

85, 1-16.

Börjesson, M., Eliasson, J., Hugosson, M.B., Brundell-Freij, K., 2012. The Stockholm congestion charges -5 years on. Effects, acceptability and lessons learnt. Transp.

Policy 20, 1-12.

Börjesson, M., Kristoffersson, I., 2015. The Gothenburg congestion charge. effects, design and politics. Transport. Res. Part A: Policy Pract. 75, 134-146. Canache, D., Mondak, J.J., Seligson, M.A., 2001. Meaning and measurement in cross-national research on satisfaction with democracy. Public Opin. Quart. 65,

506-528.

Chang, E., Chu, Y.-H., Wu, W., 2014. Consenting to lose or expecting to win? Inter-temporal changes in voters' winner-loser status and satisfaction with democracy. In:

Thomassen, Jaqcues (Ed.), Elections and Democracy: Representation and Accountability. Oxford University Press, New York.

Christiansen, P., Fearnley, N., Hanssen, J.U., Skollerud, K.H., 2016. Household parking facilities: relationship on travel behavior and car ownership. Transp. Res. Proc.

25, 4185-4195. 
Curini, L., Jou, W., Memoli, V., 2012. Satisfaction with democracy and the winner/loser debate: the role of policy preferences and past experience. Br. J. Polit. Sci. 42,

241-261.

Dahl, R.A., 1989. Democracy and its Critics. Yale University Press, New Haven.

Dahlberg, S., Holmberg, S., 2014. Democracy and bureaucracy: How their quality matters for popular satisfaction. West Eur. Polit. 37, 515-537.

Dahlberg, S., Linde, J., Holmberg, S., 2015. Democratic discontent in old and new democracies: assessing the importance of democratic input and governmental

output. Polit. Stud. 63, 18-37.

Dalton, R.J., 1999. Political support in advanced industrial democracies. In: Norris, P. (Ed.), Critical Citizens: Global Support for Democratic Government. Oxford

University Press, Oxford.

Denters, B., Rose, L.E., 2005. Comparing Local Governance-Trends and Developments. Palgrave Macmillan, New York.

Easton, D., 1957. An approach to the analysis of political systems. World Polit. 9, 383-400.

Easton, D., 1965. A Systems Analysis of Political Life. Wiley, New York.

Eliasson, J., 2017. Congestion pricing. In: Cowie, J., Ison, S. (Eds.), The Routledge Handbook of Transport Economics. Routledge, New York.

Eliasson, J., 2014. The role of attitude structures, direct experience and reframing for the success of congestion pricing. Transport. Res. Part A: Policy Pract. 67, 81-95. Eliasson, J., Jonsson, L., 2011. The unexpected "yes": explanatory factors behind the positive attitudes to congestion charges in Stockholm. Transp. Policy 18,

636-647.

Engebretsen, Ø., Christiansen, P., Strand, A., 2017. Bergen light rail-effects on travel behaviour. J. Transp. Geogr. 62, 111-121.

Erkel, P.F., Meer, T.W., 2016. Macroeconomic performance, political trust and the Great Recession: a multilevel analysis of the effects of within-country fluctuations in

macroeconomic performance on political trust in 15 EU countries, 1999-2011. Eur. J. Polit. Res. 55, 177-197.

Ezrow, L., Xezonakis, G., 2011. Citizen satisfaction with democracy and parties' policy offerings. Comparat. Polit. Stud. 44, 1152-1178.

Habermas, J., 1979. Communication and the Evolution of Society. Heinemann, London.

Hobbes, T., 1994. Leviathan. Everyman, London.

Hobolt, S.B., 2012. Citizen satisfaction with democracy in the European Union. J. Common Market Stud. 50, 88-105.

Holbein, J.B., Dynes, A., 2018 Noisy retrospection: The Effect of Party Control on Policy Outcomes. Available at http://adamdynes.com/documents/WP_2018_holbein-

dynes_noisy-retrospection.pdf.

Huang, M.-H., Chang, Y.-T., Chu, Y.-H., 2008. Identifying sources of democratic legitimacy: a multilevel analysis. Electoral Stud. 27, 45-62.

Hårsman, B., Quigley, J.M., 2010. Political and public acceptability of congestion pricing: ideology and self-interest. J. Policy Anal. Manage. 29, 854-874.

Imai, K., Keele, L., Tingley, D., Yamamoto, T., 2011. Unpacking the black box of causality: learning about causal mechanisms from experimental and observational

studies. Am. Polit. Sci. Rev. 105, 765-789.

Kant, I., 1999. Practical philosophy. In: Gregor, J. Mary (Ed.), Cambridge Edition of the Works of Immanuel Kant in Translation. Cambridge University Press,

Cambridge.

Kim, M., 2009. Cross-national analyses of satisfaction with democracy and ideological congruence. J. Elect., Publ. Opin. Parties 19, 49-72. 
Leiter, D., Clark, M., 2015. Valence and satisfaction with democracy: a cross-national analysis of nine Western European democracies. Eur. J. Polit. Res. 54, 543-562. Lijphart, A., 1999.

Patterns of Democracy: Government Forms and Performance in Thirty-six Countries. Yale University Press, New Haven.

Linde, J., Ekman, J., 2003. Satisfaction with democracy: a note on a frequently used indicator in comparative politics. Eur. J. Polit. Res. 42, 391-408.

Loughlin, J., Hendriks, F., Lidström, A., 2012. The Oxford Handbook of Local and Regional Democracy in Europe. Oxford University Press, Oxford.

Magalhães, P.C., 2014. Government effectiveness and support for democracy. Eur. J. Polit. Res. 53, 77-97.

Marsden, G., Reardon, L., 2017. Questions of governance: rethinking the study of transportation policy. Transport. Res. Part A: Policy Pract. 101, 238-251.

Mill, J.S., 1998. In: John Gray (Ed.), On Liberty and Other Essays. Oxford University Press, Oxford.

Norris, P., 1999. Critical Citizens: Global Support for Democratic Government. Oxford University Press, Oxford.

Olsen, A.L., 2017. Compared to what? How social and historical reference points affect citizens' performance evaluations. J. Public Admin. Res. Theory 27, 562-580.

Peffley, M., Rohrschneider, R., 2014. The multiple bases of democratic support: procedural representation and governmental outputs. In: Thomassen, J. (Ed.), Elections

and Democracy: Representation and Accountability. Oxford University Press, New York.

Pellegata, A., Memoli, V., 2018. Corruption and satisfaction with democracy: the conditional role of electoral disproportionality and ballot control. Eur. Polit. Sci. Rev.

10 (3), 1-24.

Peters, B.G., 2002. The politics of tool choice. In: Salamon, L. (Ed.), The Tools of Government: A Guide to the New Governance. Oxford University Press, New York. Rawls, J., 1971. A Theory of Justice. Harvard University Press, Cambridge.

Reher, S., 2016. The effects of congruence in policy priorities on satisfaction with democracy. J. Elections, Public Opin. Part. 26, 40-57.

Rohrschneider, R., 2005. Institutional quality and perceptions of representation in advanced industrial democracies. Comparat. Polit. Stud. 38, 850-874.

Rose, L.E., Pettersen, P.A., 1999. Confidence in politicians and institutions: comparing national and local levels. In: Narud, H.M., Aalber, T. (Eds.), Challenges to

Representative Democracy: Parties, Voters and Public Opinion. Fagbokforlaget, Bergen.

Rose, L.E., Pettersen, P.A., 2000. The legitimacy of local government-What makes a difference? Evidence from Norway. In: Hoggart, K., Clark, T.N. (Eds.), Citizen

Responsive Government (Research in Urban Policy, Volume 8). Emerald Group Publishing Limited, Amsterdam, pp. 25-65.

Rose, L.E., Pettersen, P.A., 2009a. Lokaldemokratiets grunnvoll: Innbyggernes politiske interesse og kompetanse. In: Saglie, J. (Ed.), Det nære demokratiet-lokalvalg

og lokal deltakelse. Abstrakt, Oslo.

Rose, L.E., Pettersen, P.A., 2009b. Lokaldemokratiets omdømme: Hvordan står det til? In: Saglie, J. (Ed.), Det nære demokratiet - lokalvalg og lokal deltakelse. Abstrakt

forlag AS, Oslo.

Rothstein, B., 2009. Creating political legitimacy: electoral democracy versus quality of government. Am. Behav. Sci. 53, 311-330.

Rothstein, B., Teorell, J., 2008. What is quality of government? A theory of impartial government institutions. Governance 21, 165-190.

Rye, T., Gaunt, M., Ison, S., 2008. Edinburgh's congestion charging plans: an analysis of reasons for non-implementation. Transport. Plann. Technol. 31, 641-661. Salamon, L.M., 2002. The 
new governance and the tools of public action: an introduction. In: Salamon, L.M. (Ed.), The Tools of Government. Oxford University Press,

New York.

Sanders, D., Clarke, H., Stewart, M., Whiteley, P., 2014. Output-oriented legitimacy: individualand system-level influences on democracy satisfaction. In: Thomassen,

J. (Ed.), Elections and Democracy: Representation and Accountability. Oxford University Press, New York.

Santos, G., 2008. London congestion charging. Brookings-Wharton Papers Urban Affairs 177234.

Schade, J., Baum, M., 2007. Reactance or acceptance? Reactions towards the introduction of road pricing. Transport. Res. Part A: Policy Pract. 41, 41-48. Scharpf, F.W., 1999.

Governing in Europe: Effective and Democratic? Oxford University Press, Oxford.

Schneider, A., Ingram, H., 1990. Behavioral assumptions of policy tools. J. Polit. 52, 510-529.

Singh, S., Karakoç, E., Blais, A., 2012. Differentiating winners: How elections affect satisfaction with democracy. Electoral Stud. 31, 201-211.

Stecker, C., Tausendpfund, M., 2016. Multidimensional government-citizen congruence and satisfaction with democracy. Eur. J. Polit. Res. 55, 492-511.

Vetter, A., 2007. Local Politics: A Resource for Democracy in Western Europe? Local Autonomy, Local Integrative Capacity, and Citizens' Attitudes Toward Politics.

Lexington Books, Plymouth.

Wagner, A.F., Schneider, F., Halla, M., 2009. The quality of institutions and satisfaction with democracy in Western Europe—a panel analysis. Eur. J. Polit. Econ. 25,

30-41.

Weber, M., 1978. Economy and society. An outline of interpretative sociology. In: Roth, G., Wittich, C., 2 vols. University of California Press, Berkeley.

Weitz-Shapiro, R., 2008. The local connection. Comparat. Polit. Stud. 41, 285-308. 
Table A.1 Descriptive statistics

\begin{tabular}{|c|c|c|c|c|c|}
\hline Variables & Mean & SD & Min & Max & Proportion 'don't know' \\
\hline Age & 44 & 16.9 & 18 & 89 & 0 \\
\hline $\operatorname{Sex}(1=$ male $)$ & 0.5 & & 0 & 1 & 0 \\
\hline Education & 3.7 & 1.1 & 1 & 5 & 0 \\
\hline Newspaper reading & 2.13 & 1.15 & 1 & 4 & 35 \\
\hline Political informed & 3.16 & 0.8 & 1 & 5 & 43 \\
\hline Perception of local politicians (index) & 2.67 & 0.66 & 1 & 4 & 635 \\
\hline Quality of public services are poor & 2.98 & 0.87 & 1 & 5 & 351 \\
\hline City council represents citizens' viewpoints well & 2.52 & 0.7 & 1 & 4 & 836 \\
\hline Not satisfied with local services & 2.22 & 0.61 & 1 & 4 & 343 \\
\hline Satisfied with land use development & 2.71 & 0.63 & 1 & 4 & 534 \\
\hline Satisfied with car accessibility & 2.78 & 0.63 & 1 & 4 & 477 \\
\hline Supports local toll roads & 2.99 & 1.22 & 1 & 5 & 196 \\
\hline
\end{tabular}


Table A.2. Variables overview

\begin{tabular}{|c|c|c|c|}
\hline Variable name & Question formulation & Categorization & Recoded values \\
\hline Education & Highest finished education & $\begin{array}{l}1=\text { Primary } \\
\text { school, } 5= \\
\text { University/college } \\
\text { four years or } \\
\text { more }\end{array}$ & $\begin{array}{l}0=\text { Primary } \\
\text { school or high } \\
\text { school, } 1= \\
\text { University or } \\
\text { college degree }\end{array}$ \\
\hline $\begin{array}{l}\text { Political } \\
\text { knowledge }\end{array}$ & $\begin{array}{l}\text { How well informed do you feel you are } \\
\text { about what happens in local politics in } \\
\text { your municipality? }\end{array}$ & $\begin{array}{l}\text { Four-point scale } \\
1=\text { Not informed, } \\
4=\text { Very well } \\
\text { informed }\end{array}$ & $\begin{array}{l}0=\text { Not informed, } \\
1=\text { Informed }\end{array}$ \\
\hline $\begin{array}{l}\text { Frequency of } \\
\text { newspaper reading }\end{array}$ & $\begin{array}{l}\text { How often would you say you read local } \\
\text { or regional news? }\end{array}$ & $\begin{array}{l}1=\text { Daily, } 2=4-6 \\
\text { times a week, } \\
3=1-3 \text { times a } \\
\text { week, } 4=\text { Fewer }\end{array}$ & $\begin{array}{l}0=\text { Seldom or } \\
\text { never } 1=\text { At least } \\
1-3 \text { times a week }\end{array}$ \\
\hline Winner & $\begin{array}{l}\text { One can feel larger identification to } \\
\text { some parties than others. For the time } \\
\text { being, which party do you feel closest? }\end{array}$ & $\begin{array}{l}\text { All parties } \\
\text { represented at the } \\
\text { local level. } \\
\text { Included "none" } \\
\text { as an option }\end{array}$ & $\begin{array}{l}0=\text { Not identifying } \\
\text { to any party in } \\
\text { government } \\
1=\text { Feel } \\
\text { identification to a } \\
\text { party in } \\
\text { government }\end{array}$ \\
\hline $\begin{array}{l}\text { Satisfaction with } \\
\text { local democracy }\end{array}$ & $\begin{array}{l}\text { How satisfied are you with the way local } \\
\text { democracy works in your municipality? }\end{array}$ & $\begin{array}{l}1=\text { Not at all } \\
\text { satisfied, } 2=\text { Fairly } \\
\text { dissatisfied } 3= \\
\text { Fairy satisfied } \\
4=\text { Very satisfied }\end{array}$ & $\begin{array}{l}1=\text { Not at all } \\
\text { satisfied, } 2=\text { Fairly } \\
\text { dissatisfied } 3= \\
\text { Fairy satisfied } \\
4=\text { Very satisfied }\end{array}$ \\
\hline $\begin{array}{l}\text { Satisfaction with } \\
\text { municipal services }\end{array}$ & $\begin{array}{l}\text { The municipal is responsible for } \\
\text { different areas within health care, } \\
\text { education, culture, sport facilities and } \\
\text { transport. All in all, do you think the } \\
\text { municipal services are.... }\end{array}$ & $\begin{array}{l}\text { Four-point scale } \\
\text { from 'not } \\
\text { satisfied' to 'very } \\
\text { satisfied' }\end{array}$ & $\begin{array}{l}1=\text { Not at all } \\
\text { satisfied or fairly } \\
\text { dissatisfied } 0= \\
\text { Fairy satisfied or } \\
\text { very satisfied }\end{array}$ \\
\hline \multirow{2}{*}{$\begin{array}{l}\text { Perceptions of } \\
\text { local politicians } \\
\text { (index) }\end{array}$} & $\begin{array}{l}\text { Politicians in my municipality are } \\
\text { sensitive for the inhabitants' viewpoints }\end{array}$ & Likert scale & \multirow{2}{*}{$\begin{array}{l}\text { Likert scale }(1= \\
\text { 'do not agree' and } \\
5=\text { 'agree' })\end{array}$} \\
\hline & $\begin{array}{l}\text { Politicians in my municipality are skilled } \\
\text { people usually knowing what they are } \\
\text { doing }\end{array}$ & Likert scale & \\
\hline $\begin{array}{l}\text { Political } \\
\text { representation }\end{array}$ & $\begin{array}{l}\text { How well does the city council reflect the } \\
\text { viewpoints of inhabitants? }\end{array}$ & Four-point scale & $\begin{array}{l}1=\text { Very or quite } \\
\text { well, } 0=\text { not at all } \\
\text { or quite little }\end{array}$ \\
\hline Political challenges & $\begin{array}{l}\text { All things considered, how satisfied or } \\
\text { dissatisfied are you with the way the } \\
\text { municipality has handled challenges } \\
\text { facing the municipality? }\end{array}$ & Scale from $0-10$ & $\begin{array}{l}\text { Scale from } 0-10 \\
(0=\text { very } \\
\text { dissatisfied and } 10 \\
=\text { very satisfied })\end{array}$ \\
\hline $\begin{array}{l}\text { Satisfied with local } \\
\text { services }\end{array}$ & $\begin{array}{l}\text { We would also know how satisfied or } \\
\text { dissatisfied you are with the following }\end{array}$ & $\begin{array}{l}1=\text { Not at all } \\
\text { satisfied, } 2=\text { Fairly } \\
\text { dissatisfied } 3=\end{array}$ & $\begin{array}{l}1=\text { Not at all } \\
\text { satisfied or fairly } \\
\text { dissatisfied, } 0=\end{array}$ \\
\hline
\end{tabular}


services ..."accessibility for cars", "city development"

Toll roads

How positive or negative are you towards the toll roads in your city?
Fairy satisfied 4=Very satisfied

Likert scale fairly satisfied or

very satisfied

$1=$ Quite negative

or very negative

$0=$ Quite positive, very positive or neither positive or negative 